\title{
Active Democratic Citizenry: A Determinant of Good Governance - A Case Study of Nigerian State
}

\section{Oladimeji Sogo Osewa}

Nigerian Defence Academy, Faculty of Arts and Social Sciences, Department of Political Science and Defence Studies, Nigeria

OrcidID: https://orcid.org/0000000337494879; E-Mail: osewa.oladimeji@gmail.com

Area/Section: Social Science.

Type of the Paper: Case Study Research.

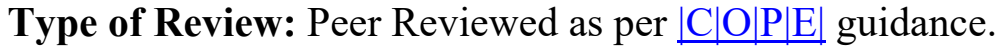

Indexed in: OpenAIRE.

DOI: http://doi.org/10.5281/zenodo.3925869.

Google Scholar Citation: IJMTS.

\section{How to Cite this Paper:}

Oladimeji Sogo Osewa. (2020). Active Democratic Citizenry: A Determinant of Good Governance - A Case Study of Nigerian State. International Journal of Management, Technology, and Social Sciences (IJMTS), 5(1), 285-297. DOI: $\underline{\text { http://doi.org/10.5281/zenodo.3925869. }}$

International Journal of Management, Technology, and Social Sciences (IJMTS) A Refereed International Journal of Srinivas University, India.

(C) With Author.

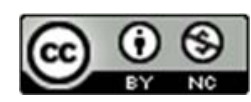

This work is licensed under a Creative Commons Attribution-Non-Commercial 4.0 International License subject to proper citation to the publication source of the work.

Disclaimer: The scholarly papers as reviewed and published by the Srinivas Publications (S.P.), India are the views and opinions of their respective authors and are not the views or opinions of the SP. The SP disclaims of any harm or loss caused due to the published content to any party. 


\title{
Active Democratic Citizenry: A Determinant of Good Governance - A Case Study of Nigerian State
}

\author{
Oladimeji Sogo Osewa \\ Nigerian Defence Academy, Faculty of Arts and Social Sciences, Department of Political Science \\ and Defence Studies, Nigeria \\ OrcidID: https://orcid.org/0000000337494879; E-Mail: osewa.oladimeji@gmail.com
}

\begin{abstract}
The activeness of any nation citizenry determines how effective and the types of government such a nation will have. In the case of Nigeria, Nigerian citizens have been engulfed by stark illiteracy and chronic ignorance. Citizens have failed in their responsibility of participating actively in the polity of their nation. Citizens have been blindfolded that they cannot even differentiate between good governance and bad governance, as they still blindly pledge their support to bad leadership and to the decayed political parties of Nigeria, e.g. APC and PDP. Citizens found mostly in this blindness are the South western citizens despite their level of education. This paper examined the inability of Nigerian citizens to read within the lines and understand the dangers inherent in the politics of these two political parties of APC and PDP, and the fact that both parties have no better ideology and plans to better the lives of Nigerians. The paper examines the difference between People's Democratic Party (PDP) and All progressive Congress (APC) ideology in terms of corruption in Nigeria. The paper finally examines the effect of non-democratic citizenry in Nigeria. This paper adopts the hybrids method, as interview methods of data collection are adopted while other data are gotten from the readymade works of scholars and from the common sense views of the writer. This paper finally proffers workable recommendations to the problems of bad leadership in Nigeria.
\end{abstract}

Keywords: Good governance, Citizenry, Nigerians, Quality citizenry, Active democratic citizenry, PDP, APC.

\section{INTRODUCTION :}

Active democratic citizenry most of the time determine the political status of their country's and the realization of good governance in their countries. Active democratic citizens participate actively to a large extends in making viable foreign policy of their countries on one hand, and actively participate in formulating local governmental policies of their countries by influencing governmental policies to the betterment of the country at large. Inclusive citizens participation in public affairs is not a new concept as many countries have wide ranging initiatives that promote citizens involvement in governing and decision-making processes, from budgeting processes to water management and environmental protection programs, citizens participation is regarded by some as a crucial mechanism in the pursuit of a sustainable and democratic process
(T.H.A.L.G, 2018) [1]. However, for citizens to be able to participate actively in governance, or in politics of their countries, such citizens need to be politically educated.

Nigerian citizens have mostly demonstrated their lack of political education as they have for years been pledging their supports to the defective political parties of APC and the PDPs that their government has failed the country on many occasions as self-centeredness, highhandedness, corruption, and bad governance have been the order of the day while governmental policies are determined based on religious and ethnic consideration. Religion and ethnicity of the president in power in Nigeria, mostly in the present government determines the appointees of government or citizens that are appointed in public offices. The appointment of Buhari is lopsided and not in the best interest of the country. Of the 
seventeen appointments made by Buhari so far on his assumption to power in 2015, seventeen are from the north, while five are from the south (Eme and Onuigbe, 2015) [2]. This has indeed shown sentiments in terms of tribe, and a violation of the federal character principles. Such an act greatly reflected tribalism, nepotism, religious bigotry and a pointer to the presidents ill-motivated aspiration to Islamize the country, and which must be resisted (Eme and Onuigbe, 2015) [2]. It is in view of the above that this paper examined the continued support of citizens for the two deceptive political parties of APC and PDP, and why citizens of Nigeria have not made their decision to give support to new political parties as a trial in Nigeria.

\section{STATEMENT OF THE PROBLEM :}

The quality or activeness of a nation citizenry determines the robustness of the governmental policies of such a nation. An active democratic citizenry tends to criticized bad government policies and other defective actions of their government. Politically liberated citizens will actively participate in the making of policies and can force their government to take up their roles in guarantee welfare of all in the state. How politically educated citizens are, also determines the politics that will at the long run determine the actualization of good governance in the state. It is a pitiable sad condition that Nigeria citizens are not politically educated as most of the citizens in Nigeria could not determine the polity of the state. Citizens could not differentiate between how it is and how it ought to be, as they blindly support political parties with defective political ideas. How it is, is corruption which had become norms in Nigeria. This is the major problem, as only small numbers of Nigerian citizens are on their toes in agitating for good governance. Corruption had overwhelmed Nigeria that the political structure of the country had been bastardized by corrupt and inept leadership, as they and their political parties are being supported by the politically blinded citizens, hence bad governance in Nigeria. It is against this backdrop that this paper examines the causes of citizens continued support for the two deceptive Nigerian political parties of APC and PDP. The paper examines the difference between the two parties of APC and PDP in terms of corruption in Nigeria. The paper finally examines the effect of Non-Democratic citizenry on the governance of Nigeria.

\section{Research Questions}

- Why do Nigerian citizens continue pledging their supports to APC and PDP?

- What is the difference between the APC and PDP ideology in terms of corruption?

- What is the impact of non-active democratic citizenry on the governance of Nigeria?

\section{The aims and objective of the paper}

- To examine the causes of citizens continued support for the two deceptive political parties of APC and PDP in Nigeria

- To find out the difference between the ideology of the two political parties of APC and PDP in Nigeria

- To examine the impact of non-active democratic citizenry on Nigeria's governance

\section{Research Assumptions}

- Illiteracy and ignorance are the causes of citizens continued supports for APC and PDP in Nigeria

- There is no difference in the ideology of APC and PDP in Nigeria

- Non-active democratic citizenry in Nigeria have a great impact on the governance of Nigeria

\section{Significance of the study}

This study is significant in that its serves as an eye opener to Nigerian leaders, political party loyalist and other citizens, on the fact that politicizing towards actualization of good governance in Nigeria should be the first priority to all Nigerians both the leaders and the followers. The paper encourages citizens on the need to forsake the deceptive political parties of APC and PDP, towards supporting new political party that may guarantee citizens welfare, hence good governance in Nigeria. This paper will serve as a source of valuable information's to student, researchers, and authors carrying out research in similar areas.

\section{CONCEPTUAL CLARIFICATION :}

\subsection{WHO IS A CITIZEN?}

According to Webster (1828) [3], a citizen is an inhabitant of a city or town especially one entitled to the right and privileges of a free man. A native or naturalized person who owes allegiance to a 
government and is entitled to protection from it. Collins Dictionary (2019) [4] defines a citizen as someone who is a citizen of a particular country, is legally accepted as belonging to that country. Citizen is a legal member of a state having been recognized by the laws of that country, and a person who owes allegiance to the country and who in turn received protection from the same country.

\subsection{GOOD GOVERNANCE}

According to the Cambridge dictionary (2019) [5], good governance is the effective and responsible management of an organization, a country, etc. which includes considering society needs in the decisions it makes. IFAD (1999) [6] posits that good governance is seen as the manner in which power is exercised in the management of a country's economic and social resources for development. Nevertheless, quality citizenry can be seen as how educated, enlightened, and liberated in terms of mind and thought the citizens of a country is. A quality citizenry can contribute to the polity and policies of the government of their country. They can also contribute by participating actively in the country's political decision making. Quality citizenry is in other wards called activedemocratic citizenry.

"Active citizenship generally brings the debate of right versus responsibilities into play given the rights by our constitution. People have a certain right to join politics or to criticizing bad leadership. Their ability to select and support good candidates and political parties with integrity call for good governance, responsibilities to uphold" (OUTA 2018) [7]. Citizens choice of candidates and political parties to determine the types of government a country will have in power. Good choice of political party and candidacy resort to good governance and vice-versa.

\subsection{THE MAIN DISCUSSIONS :}

It is a fact that how educated, enlightened and liberated citizens of a country are, determines how good the polity of such country would be, and how possible is the actualization of good governance in such a country. Before we dabble into the main discussion, we shall use the Plato's allegory of the cave to explain the blindness and ignorance of Nigerians, especially Nigerian political party loyalist. The allegory of the cave was presented by the Greek philosopher Plato in his work called
Republic (514a-512a) to compare the effect of education and lack of education on our nature. It was analyzed that "it is written as a dialogue between Plato's brother glaucon and his mentor Socrates, narrated by the later. The allegory as analyzed in Plato's work is presented after the analogy of the sun (508b-511e). All three are characterized in relation to dialectic at the end of books vii and viii of the work (531d-534e).

It is analyzed that Plato has Socrates describe a group of people who have lived chained to the wall of a cave all of their lives, facing a black wall. And that the people watch shadows projected on the wall from objects passing in front of a fire behind them, and give names to these shadows. The shadows are the prisoner's reality. It was analyzed that Socrates explains how the philosopher is like a prisoner who is freed from the cave and comes to understand that the shadows on the wall are not reality at all, for he can perceive the true form of reality rather than the manufactured reality that is the shadows seen by the prisoners. He argued that the inmates of this place do not even desire to leave their prison, for they know no better life. The prisoners manage to break their bonds one day and discover that their reality was not what they thought it was. Socrates argued that they discovered the sun, which Plato uses as an analogy for the fire that man cannot see behind. Like the fire that casts light on the walls of the cave, the human condition is forever bound to the impressions that are received through the senses. Even if these interpretations (or, in Kantian terminology, intuitions) are an absurd misrepresentation of reality, we cannot somehow break free from the bonds of our human condition-we cannot free ourselves from phenomenal state just as the prisoners could not free themselves from their chains. If, however, we were to miraculously escape our bondage, we would find a world that we could not understand; the sun is incomprehensible for someone who has never seen it."

Nevertheless, Nigerians and party loyalists are ignorant of what is really going on in the present government and even the past government of Nigeria. Nigerian citizens do not know good governance because they have been trapped in the cave as submitted by Plato. What the citizens see and know of Nigerian party leaders, politicians and 
political parties in Nigeria, especially the APC and the PDP are deceptive views that are not the realities, because citizens and party loyalist could not see the realities, and understands the devilish act of these politicians, they blindly and ignorantly pledge their support to this two deceptive political parties. it is high time Nigerians look forwards to forsaking this two deceptive parties and go for better options by trying new political parties.

It is quite unfortunate that very large numbers of Nigerians are still living in the dark suffering from stark illiteracy and ignorance; many are unable to read within the lines despite the deadly revelations, actions and deeds of Nigerians ethnic, political and religious actors. The writer has always been concluding that Nigeria has never had practically working government, because Nigerian government has failed the citizens on many occasions. Nigeria since $80 \mathrm{~s}$ has never had government or leaders who have the interest of the masses as the uppermost in their hearts, and leaders that are ready to make prevailed altruism. Nigerian leaders have failed to give to citizens the basic necessities of lives that will enhance livelihood and guarantee high standard of living of Nigerians. According to Jeremy Bentham (1989) [8], the father of utilitarianism, during his explanation on pain and pleasure, he submits that every government and the legislators should govern and make a law that will call for the greatest happiness of the greatest number of people. This idea has not been practicalised in Nigeria.

Despite the failure by Nigerian leaders, selfishness, and the wickedness of Nigerian leaders, displayed on the citizenry, quite very large numbers of Nigerian citizens still ignorantly pledge their loyalty and support to these selfish leaders. The writer felt so sad whenever he sees citizens of Nigeria singing songs of praises of these selfish leaders, giving them full support in polity even at the detriments of their lives. Citizens who belong to different political parties engaged in a series of unnecessary arguments and deadly attacks of their fellow citizens. Citizens are so ignorant and unenlightened that some have pledged their support simply because of religious affiliation, some because of ethnic linkages, political party loyalty, and material gains, even the academia's that were supposed to be criticizing, have become boot leakers and elite lackeys as submitted by Alabi (2019) [9]. Others have pledged their support because of their inability to differentiate between right and wrong. Some were born into this political decadence of Nigeria and unable to differentiate between how it is and how it ought to be.

The writer was fortunate to have a series of discussions with some citizens, on the selfishness of Nigerian leaders. So many citizens concluded that the way the country is going now is the right way it should, and that, there is no other way better. Some even asked the writer a question," if you are fortunate to be the president of Nigeria today, tell me, won't you embezzle public fund?" Another person even said that the 2015 general election was between the Christians and the Muslims, to him, APC belongs to the Muslims while PDP belongs to the Christians. Can you see the level of citizen's ignorance? Just in this political party campaign all over the country in this 2019 , quite a number of Nigerian citizens have lost their lives, either being attacked by other political party thugs or by motor accidents. The accident that happened during the APC political party rally in Lagos, Festac Town Amuwo Odofin to be precise in early February 2019 claimed about three lives including one local government staff called Efe and several others injured. (source, eye witness) I doubt if the family of this deceased were compensated. They all died as ignorant, what a pity.

For a few years now, there has been a power struggle between the two prevailing political parties of APC and the PDP, many Nigerians have ignorantly pledged their support again to one of this two parties, some have been cheaply brainwash to argue in support of the APC believing that the PDPs are corrupt, while the PDPs loyalists have criticized the APC government on their failure in areas such as economy, security and the one sided appointment of officials to man some sensitive post in the country such as the security, and the ministerial positions. These are the questions needed to be addressed. Are the PDPs truly corrupt? Are there any differences between the two parties of APC and PDP? Is the formation of the two political parties not made up of same powerful men? is APC leader and other powerful men in APC not corrupt too? Are the hands that brought the leadership of the present 
administration to power not corrupt? These are the questions that have been addressed below. To the writer, by now Nigerians should not be talking of APC and PDP had he being citizens are truly liberated in thought.

The simple truth is that there are no meaningful differences between APC and PDP. Truly the past government of PDP was full of corrupt practices at its highest order. For example, there was a charged of embezzlement of public fund against the formal Minister for petroleum Dieziani and that of the case of 2 billion dollars budgeted to buy ammunition which was claimed to have been embezzled by Sambo Dansuki and others during the Good luck Jonathans Administration 2011-2015. Countless charges of corruption have been raised against the past government of PDP in the past. PDP is indeed very corrupt. However, the APC present governments 2015-2019 have been caught in the same trap. There have been cases of embezzlement of public funds against Bashir Lawal, formal secretary to the federal government in 2017, and that of Maina that has to do with the embezzlement of pensioners money in 2016, Maina was removed from office, and was later reinstated by President Muhammadu Buhari which prompted agitations by

TABLE 1: THE NAMES AND STATE OF THE DEFECTEES

\begin{tabular}{|c|c|}
\hline NAMES & STATE \\
\hline Senator Bukola Saraki - & kwara state \\
\hline Ingineer Ibrahim Kwakwanso & Kano state \\
\hline Senator Dino Melaiye & Kogi state \\
\hline Rotimi Amechi & Rivers state \\
\hline Gov Samuel Ortom & Benue state \\
\hline Alhaji Atiku Abubaka & Adamawa state \\
\hline Senator Umaru Dahiru & Sokoto state \\
\hline Senator Magnus Ngei Abe & Rivers state \\
\hline Senator wilson Asinobi Ake & Rivers state \\
\hline Senator Bindawa M. Jibrilla & Adamawa state \\
\hline Senator Muhammed D Goje & Gombe state \\
\hline Senator Aisha J Alhasan & Taraba state \\
\hline Senator Muhammed A Ndume & Borno state \\
\hline Senator Mahammed S Lafiaji & Kwara state \\
\hline Senator Abdulahi Adamu & Nasarawa state \\
\hline Senator Ibrahim A Gobir & Sokoto state \\
\hline Senator Banabas Gemade & Benue state \\
\hline Senator Lanre Tejuoso & Ogun state \\
\hline EX Edo Gov.Osarhemen Osunbo & Edo state \\
\hline Maj Gen. Charles Arhiavbere (rtd) & Edo state \\
\hline Gbemisola Saraki & Kwara state \\
\hline
\end{tabular}

Oladimeji Sogo Osewa. (2020); www.srinivaspublication.com

\section{Nigerians.}

The fact is that how can we prove the integrity and cleanliness of the present administration and his kins men in government when the hands that brought the present leadership to power are not saint. As Tinubu, Amechi, Oshiomole, and others were the driving force; you can understand what $i$ mean. There have been grudges between Bola Tinubu and the formal governor of Lagos state Babajide Raji Fashola and the present governor Ambode which was a case that no one can really trace the causes, but could be financial issue based on citizen's speculations. These have led to the withdrawal of Tinubu's supports for Ambode's second term agenda in Lagos. Where does the innocence of Bola Tinubu lies? Very large numbers of PDP members were seen to have defected from PDP to APC in 2014, 2015, and in 2016, this was the same PDP members seen to be corrupt, yet they were accepted into the party and even given sensitive positions to man. Yet APC government claimed to be honest. Below are some of the PDP members that defected to APC during the aforementioned year, even though some had recently decamped back to PDP. 


\begin{tabular}{|lc|}
\hline Dr Olusola Oke & Ondo state \\
\hline Ahamed Mahmud & Jigawa state \\
\hline Michael Aondoakaa formal AGF & --------- \\
\hline Mrs Ayoka Lawani & Oyo state \\
\hline Hon. Mamman Alkalio & Gombe state \\
\hline Mrs Eunice Uzo Kalu & Abia state \\
\hline Hon. Nnanna Uzo Kalu & Abia state \\
\hline Mrs Mascot Uzo Kalu & Abia state \\
\hline Hon Yakubu Dogara & ----------- \\
\hline
\end{tabular}

Source-Vanguard Newspaper (2014) [10]

The above list is not an epitome of perfection as it is subject to corrections in any way. However, the above list signifies that both parties are made up of same people with same orientations and ideology. The most annoying is the lackadaisical attitudes of APC government in raising allegations of corruption against those defectees because they now belong to APC. Once a corrupt politician's defect to APC, they are saved and their sins are automatically forgiven, yet APC government claims they are fighting corruption. It is therefore a fact that the fight against corruption agenda of the APC government is one sided, and it will have no positive effect, it is going to be nothing but a fleeting mirage. Despite the above analyses, many citizens especially from the Yoruba tribes could not read within the lines and still blindly pledge their support to these two deceptive political parties, this is indeed a pitiable dismal.

The present government had also totally violated the federal character principles by appointing personnel's only from the northern region to man most of the sensitive positions especially the positions that has to do with the security of the nation, yet some non-liberated citizens especially from the Yoruba's sees nothing wrong in this. Permit the writer to clarify the fact that Nigeria is a federation that is made up of three major tribes and more than 250 ethnic groups and religion, so no ethnic group, tribe, or religion should be given more interest or recognition ahead of or in expense of others. There should be equality and social justice to all tribes and religion when it comes to appointing officials into public offices.

In the federal character principles, according to part one(1) of the sections of the federal character commission-its states that an act to establish the federal character commission with responsibility to promote, monitor and enforce compliance with the principles of the proportional sharing of all bureaucratic, economic, media, military, and political posts at all levels of government. The president has violated these principles by appointing most of the officials below.

\section{TABLE 2: THE SERVICE CHIEFS APPOINTED BY PRESIDENT BUHARI IN HIS FIRST TERM} IN NIGERIA

\begin{tabular}{|lcc|}
\hline NAME & OFFICE & STATE \\
\hline Brig Gen Monsur Dan Ali (rtd) & Minister for defence & Zamfara state \\
\hline Abayomi G. Olonishakin & Chief of defence staff & Ekiti state \\
\hline Maj Gen T.Y. Buratai & Chief of army staff & Borno state \\
\hline Rear Adr Ibok Ete E. Ibas & Chief of naval state & Cross Rivers state \\
\hline A.V.M Sadique Abubaka & Chief of air staff & Bauchi state \\
\hline A.V.M Monday Riku & Chief of defence intelligence & Plateu state \\
\hline Maj Gen Babangana Monguno (rtd) & National Security Advisor & Borno state \\
\hline LT Gen Abdulranman Danbazau (rtd) & Minister for interior & ------------- \\
\hline Mr Ibrahim Magu & Head, EFCC & -------- \\
\hline Muhammed Adamu & IG, Police & Nassarawa \\
\hline Abdullahi Muhammadu & Head, NSCDC & Niger state \\
\hline
\end{tabular}




\begin{tabular}{|lcc|}
\hline Lawal Musa Daura & Head, DSS & Katsina state \\
\hline Muhammed Babandede & Head, Immigration & Jigawa state \\
\hline Col. Hammed Ibrahim Ali (rtd) & Head, Custom service & Kaduna state \\
\hline Ja afaru Ahmed & Head, Prison service & -------------- \\
\hline C. Marshal Boboye Oyeyemi & Head, FRSC & Kwara state \\
\hline
\end{tabular}

Source- Punch Newspaper (2016)

It's quite unfortunate that many Nigerians still perceive the struggle and rivalry between the two prevailing political parties of APC and PDP as a child of necessity, while the country is gradually going A-wire. Evidence has shown that the administration of this country is no longer in the hands of the leadership of the present administration, not even in the hands of APC politicians, but in the hands of strong power (cabals) in Nigeria as posits by Aisha Buhari. These cabals are ruling Nigeria by their stooges and loyalist. Orders come from above (from the cabals). These sets of cabals ruling Nigeria possesses the character of an extremist.

Their loyalist abounds around Nigeria and this is the major reason while Nigeria is experiencing killings all over the country. The analysis below will explain better. The cabal's mission is yet to be fully revealed. The deadly activities of the Fulani herdsmen were in the past limited to high way robbery, and limited cases of farmers-herdsmen clashes, however, since the inception of the present administration, farmers-herdsmen clashes have risen drastically with increased newer cases of Kidnapping, armed banditry which have claimed many lives and increases the death toll in Nigeria. The first time in the history of Nigeria, the Miyetti Allah openly threatens to continue killings in Nigeria if ranching is not approved, yet the leadership of Miyetti Allah was not arrested for such comments. The military have also been penetrated as they are no longer given enough arms and ammunitions to prosecute the war against Boko Haram. This is why we have massive killings and attacks on the military Base across northeastern Nigeria. Many personnel's

have been sent to their early grave including active commanders such as Col Ali Abu and LT Col Ibrahim Sakaba (Osewa, 2019) [11]. Virtually all the state of the federation is affected, but because the killings have not really spread down to other region, especially the south west, most of the Yoruba's and the Igbo's have not really felt the pains, and these is why you found them blindly pledging their support, and continually engaging themselves in Nigerian APC and PDP dirty party politics.

Most Nigerians including many top politicians in Nigeria still don't understand or know that this country, Nigeria is gradually metamorphosing into a strange highland. Nevertheless, this have been exposed to some of Nigerian top politicians e.g., Olusegun Obasonjo, Theophelous Danjuma, Abdulsalami, etc and that was why this present government of Buhari is no longer being supported by the aforementioned names for second term. The aforementioned politicians may have their own selfish interest around the corner as some citizens have argued, however, they have really spoken the mind of many Nigerians which has to do with the Islamization and Northenization of the country. However, let us be aware of the fact that PDP is corrupt, Atiku Abubaka is not the messiah, but a government that is corrupt, $\mathrm{i}$ believe is better than a government that does not care about the security of lives and properties, and a government that does not have any respect for human right. The best option would have been to galvanize support for a new political party that has integrity, but because Nigerian citizens are not enlightened and liberated in terms of thought, the idea to pick up, and galvanize support for new political party, other than PDP and APC became unrealistic.

Formal president Olushegun Obasanjo would have preferred using new political party, and support new candidates in the past 2019 general election, but because the citizens are still living in the dark and were not on ground to give their support to this new political party, the idea become unrealistic. Obasanjo initially try to marge other political parties, the one he called the political third force. But quite unfortunate that it was too late for this third force to make head ways, and the citizens were also not on ground to even support the third 
force, instead they still blindly go for the two deceptive parties of APC and PDP. Because Olusegun Obasanjo wanted president Buhari out of power at all cost, he then reconsidered Atiku which was still seen as better option when compared to the present leadership. According to Obasanjo in 2019, he posits that Atiku is not the messiah, not the best option, but better than the leadership of the present government.

\section{THEORETICAL FRAMEWORK :}

\subsection{THE SYSTEM THEORY}

The system theory was first popularized by David Easton (1953) in his political system and elaborated more on it in 1965 in his "two books, a framework for political analysis and system analysis of political life',. This theory is used to explain the political system and how it works. The system has been relevant to other areas of knowledge such as sociology, psychology, etc. As analyzed in Anifowose and Enemuo (1999) [12], they posit, according to Easton, a political system is that system of interaction in any society through which binding and authoritative allocations are made". They went further that 'Easton analyses political activity by employing the paradigm of the biological system whose life processes interact with each other and with the environment to produce a changing but nonetheless stable bodily state". They submit "viewed this way, therefore, public policy is the response of the political system to forces brought to bear on it from the environment". "system theory portrays public policy as an output of the political system". However, the forces from the environment (citizens) in Nigeria is so faulty that it has also brought forward a faulty politics and political activities which has given birth to corruption and the enthronement of corrupt leaders in government. The fact that Nigeria lack active democratic citizenry who can criticize faulty policies of

TABLE 3 : THE TABLE SHOWING THE STATUS OF RESPONDENTS

\begin{tabular}{|c|c|c|c|l|}
\hline S/N & NAME & ROFESSION & EDUCATION & $\begin{array}{l}\text { DATE OF } \\
\text { INTERVIEW }\end{array}$ \\
\hline 1 & MR JAMES & TEACHER & B .ED. & $20^{\mathrm{TH}}$ NOV, 2019 \\
\hline 2 & MR AYOMIDE & BUSINESS MAN & B.SC. & $20^{\mathrm{TH}}$ NOV, 2019 \\
\hline 3 & MR FEMI & LAWYER & M.LL. & $20^{\mathrm{TH}}$ NOV, 2019 \\
\hline 4 & MRS GRACE & ACCOUNTANT & B.SC. & $21^{\mathrm{ST}}$ NOV, 2019 \\
\hline 5 & MRS SHOLA & FRONT DESKOFF & HND & $21^{\mathrm{ST}}$ NOV, 2019 \\
\hline
\end{tabular}

Oladimeji Sogo Osewa. (2020); www.srinivaspublication.com

PAGE 293 government, and criticized bad political party leaders, as citizens blindly support bad political parties with faulty party ideology. This has now sent a message into the conversion box (the political system) through the throughput, which has been sent out as the output into the environment and leading to bad governmental policies, faulty polity and enthronement of bad leadership in Nigeria. That is to say, there is every possibility of out to be active democratic citizenry who can determine the types of political parties needed and the type of leaders wanted.

\section{METHODOLOGY :} paper is hinged on the hybrid method. That is the tool for data collection is interview, readymade works of scholars, while other data are from the common sensical views of the author. The study adopted the case study Design, as the case of Nigerians continued support for the two deceptive political parties of APC and PDP is examined. The population for this study is Nigerian citizens as a whole. While samples are taken by applying purposive sampling technique that allows only those Nigerians that are educated and can understand the rot in Nigerian prevailing political parties of APC and the PDP to be interviewed. This can be realized through asking about the respondents' level of education, their profession and their level of political participation. Ten (10) samples are taken, meaning that ten (10) respondents are interviewed. The study is carried out in Lagos and Ekiti state. The response gotten from the respondents interviewed are thematically analyzed, as findings are drowned based on the respondent's submissions. good governance in Nigeria, only if citizens turn

The method through which data is collected in this 


\begin{tabular}{|c|c|c|c|c|}
\hline 6 & $\begin{array}{c}\text { MRS } \\
\text { OLUWASEUN }\end{array}$ & BIOCHEMIST & M.SC. & $24^{\mathrm{ST}} \mathrm{NOV}, 2019$ \\
\hline 7 & MR CHUCKS & BUSINESS MAN & B.SC. & $24^{\mathrm{TH}} \mathrm{NOV}, 2019$ \\
\hline 8 & 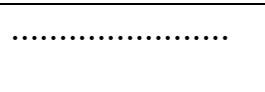 & $\begin{array}{ll}\text { LOCAL } & \text { GOV'T } \\
\text { STAFF } & \end{array}$ & M.SC. & $25^{\mathrm{TH}} \mathrm{NOV}, 2019$ \\
\hline $\begin{array}{l}9 \\
10 \\
\end{array}$ & MR MACHIEL & $\begin{array}{l}\text { LECTURER } \\
\text { POL/SCIENTIST }\end{array}$ & $\begin{array}{l}\text { M.SC. } \\
\text { B.SC. }\end{array}$ & $\begin{array}{l}25^{\mathrm{TH}} \mathrm{NOV}, 2019 \\
26^{\mathrm{TH}} \mathrm{NOV}, 2019 \\
\end{array}$ \\
\hline
\end{tabular}

Source field survey 2019

The total of ten (10) respondents were interviewed, made up of seven (7) males and three (3) females, five (5) university graduates, four (4) masters degree holder and one (1) HND holder.

\section{DATA PRESENTATION AND ANALYSIS :}

\subsection{INTRODUCTION :}

This section is designated for the presentation and analysis of data gotten from the respondents interviewed on the field. Each of the assumptions articulated is also tested, while responses are thematically analyzed. Each respondent is coated verbatim in order not to lose the validity of the information gathered. Findings are drowned based on the opinions of the respondents, while the author finally put forward some recommendations.

Test of assumption one (1). Illiteracy and ignorance are the causes of citizens continued support for both political parties of APC and PDP in Nigeria. Respondents were asked to comment on the causes of Nigerian citizens continued support for the defective political parties of APC and PDP in Nigeria. Most of the respondents agreed that illiteracy and poverty is the causes of citizens continued support for both parties, despite the fact that both parties had failed Nigerians, citizens still pledge their support to them.

The first respondent, a lecturer submits that; Nigeria is a country where majority of the citizens are living below the poverty line, due to this, citizens based on their poor condition are always at the mercy of the politicians that give stipends either in cash or commodities, as citizens end up supporting any politicians that give out bribe in order to be voted for. Impoverishing the citizens is a strategy in Nigeria through which citizens fall easily into the hands of the politicians, as no other political party or their candidate other than the APC and the PDP can afford to give out huge amount of money as bribe for support during electioneering. Other people also support because the candidates is from their tribe or their religion. So, you can see the level of ignorant.

Another respondent, a teacher opined that, the reason is nothing other than poverty. You know that there is a belief amongst Nigerians that once politicians get to power; they end up not remembering citizens that voted them to power. What they will then remember is them, their family and their party leaders so citizens mostly received a bribe from the politicians during the campaign, based on the belief that they may not receive any benefit from the candidates when they get to the position of authority.

A respondent, businessman also submits that, what causes it is poverty and ignorance. We have seen so many political party loyalists that are very poor, most of the party members are just like a rag used and dumped, but yet they still follow the party ignorantly because of the little money they do give to them. I have some of them (political party members) in my area. Sometimes when they go to their meeting, they came back home with as small as a rubber of rice and \#200. With all this, they still can't think, as they still keep following the party and party leaders that take all the gain when they eventually get to power.

Test of assumption two (2). There is no difference in the ideology of APC and the PDP political party in terms of corruption. Respondents were asked to air their opinions on the differences between the APC and the PDP ideology in terms of corruption. Most of the respondents agreed that both parties are corrupt looking at both parties antecedents.

The first respondent, a lawyer submits that, I would say that there are no much differences between APC and the PDP when it comes to the issue of corruption. Both are corrupt parties. As we can recall a series of corrupt cases of embezzlement of public funds meant for public utilities by officials 
in both administration in the past. I would not want to mention any case, but quite a number of Nigerians know what I mean. The issue of the losing party members during election decamping to the winning or ruling party, while they are even accepted and welcomed to the ruling party by the ruling party leadership is even a sign that the composition of both parties is the same. When there is a case of corruption against you, as a member of the former administration, once you decamped to the ruling party, you became a saint as your pending case of corruption will be closed automatically. Is that not corruption?

Another respondent, a local government staff argued that, to be candid, both administrations formed by both political parties are not innocent of corruption. None of them is totally free from corruption. The only thing we can say is that the level of corruption differs, as cases of corrupt allegations during the PDP era is more than that of the APC and we can't tell what will happen in this APC second term administration. But nevertheless, both administrations had failed Nigerians.

A respondent, Front Desk Officer in a bank, submits that, to me, i will always say that Nigeria for years now has not had a good government that is ready to truly serve the people. The sincere thing about both political parties is that they want to be in power, not because they want to serve the people but because of their own selfish interest. You can see the rate of poverty in Nigeria, does this country looks like a country with government that cares about the people? Absolutely no. They only want to enrich themselves.

The last respondent here, a biochemist, argued that there is no difference between APC led government and that of the PDP past administration. Both have not contested to be in power because they want to better the lives of the people, but because they want to fill their personal pulses. Despite the resources that God has given to this Nation, we don't expect Nigerians to be suffering and struggling like this if our leaders are honest. Many Nigerians cannot survive, yet our senators, governors and presidents are becoming richer day by day.

Test of assumption three (3). Non-active democratic citizenry in Nigeria affect governance in Nigeria. Respondents were asked to submit their opinions on the impact of non-active democratic citizenry in Nigeria, on the governance of the country. All of the respondents agreed that active democratic citizenry can actively participate in breeding good governance.

The first respondent, a political scientist posits that, an active democratic citizenry can always scrutinize the actions and policies of government at all time, ensuring that government is governing in accordance to the stipulations of the constitution, and will always frown at arbitrary rule by the government. But the reverse is the case in Nigeria, as most citizens are illiterate that tend to be apolitical because they are not enlightened. Citizens in Nigeria cannot unanimously rise against bad policies of the government in Nigeria, because they cannot speak in one voice, as opinions and ideas differ. So, this is the problem and is the reason for bad governance in Nigeria.

Another respondent, an accountant submits that, the impact of non-active democratic citizenry in Nigeria is that, it affects governance. Citizens are always not able to rise against any action of the government that is not favourable to the people. They are always afraid of been arrested by the government, so due to this, they remain silent and be dying in the silence of the unfavourable decisions of the government.

The last respondent, a business man argued that the impact is injurious to the nation because there will be no body to check the excesses of the government. That is why in Nigeria, government does not seek the opinion of the citizens as expected before some policies are made. The reason is that citizens are not that active in speaking in one voice against bad policies of the government. This is why sometimes Nigeria is been governed only based on the individual leadership idea, not in accordance to the constitution or public interest.

\section{FIELD SURVEY FINDINGS :}

In regards to the submissions of the respondents above, this study thereby finds out that there are no much differences between the two political parties of APC and PDP in terms of corrupt ideology. The study revealed that both parties are not willing to be in power mostly because they want to better the lives of the people, but because of their own selfish 
interest.

The study also finds out that the causes of citizens continued support to both deceptive political parties of APC and the PDP is nothing but poverty, illiteracy and ignorance ravaging the people. Citizens in Nigeria are submissive to these two political parties because they have the capacity to bribe the poor citizens, while other citizens ignorantly support because of religion and tribal affiliations.

The study finally revealed that the bad governance in Nigeria is as a result of the non-active democratic citizenry in Nigeria. Most citizens are illiterate who cannot understand the deteriorating nature of the country, not to talk of rising against bad leadership. And this is one of the reasons for bad governance in Nigeria.

\section{CONCLUSION :}

Actualization of good governance is greatly determined by the quality of citizenry that a nation has. How educated and enlightened the citizens of a country his, and their active participation in politics of their country en-route good governance. This write-up will serve as an eye opener to so many Nigerians blindly pledging their supports to deceptive political party leadership. And as quick as possible Nigerian citizens are able to retrace their track, as quickly we shall have good governance in Nigeria, and Nigeria shall be great again. The idea of Nigerians pledging their support to the two deceptive political parties of APC, PDP and their party godfathers is a doom on the country and even a clear sign that Nigerians are still living in the dark, not liberated. The attitudes of Nigerians are like that of a dog, in which his master left him unfed and goes out for many hours. When his master came back, instead of the dog to be hostile to the master, he began to shake his tail crying that he has been in Unger for long. The master would now give him little food just to sustain him and send him on an errand to the enemy, and the dog will begin to shake his tail praising his master for taking care of him. The dog was not aware of the fact that it is the duty of his master to take good care of him under the law and that what he gives to him is his own right under the law, not as if the master is nice to him at all. The dog may go on the errand and never come back again. That is exactly the situation in Nigeria. Nigerian leaders use the strategy of Unger to subject the citizens under their control. The leaders will give little out of the right of the citizens to them just to make them subject to their control during the election and to vote them to power, while citizens do not know that the money giving to them belongs to the nation and one meant to take care of the people of the country at large. The citizen's ignorantly run after such leaders seeing them as good people and a friend of the paupers, not knowing that what they are being given is little out of their right, but they will end up singing songs of praises of such leaders and ignorantly vote them in again. It is a pitiable sad condition. Section 14 (2b) of the constitution of the federal republic of Nigeria (1999) state, that the purpose of Nigerian government is to guarantee the security of lives and properties and ensure welfare of all Nigerians. Let all Nigerians note these above constitutional stipulation and endeavour to fight for their right of welfare in all ramifications of life. God bless Nigeria.

\section{RECOMMENDATIONS :}

We believe that this submission will serve as an eye opener to many Nigerians that politicians are not God; politicians cannot live without the citizens. They have failed to give to all citizens the basic needs of lives because of their own selfish interest in enriching themselves. Despite this, Citizens still sing songs of praises of these bad leaders, while they (citizens) are suffering and smiling. Citizens right need to be jealously guarded, let the citizens stop being ignorant, Sincerely Nigerians can force their leaders to do good by not given them support and unnecessary recognitions. They can't live without the citizens. The force theory says humans are bad, wicked, they know good but will never want to do good except they are forced to do good. Let Nigerians force their leaders to do well through continuous unanimous agitations and peaceful protest and also stop the idea of receiving money and commodities from the politicians to support them during election. Supporting a political party's candidate because of religion and tribal affiliation is a bad idea that leads to the enthronement of bad leadership in Nigeria. As we do all this, Nigeria shall rise again. I sincerely recommend that Nigerians should endeavour to withdraw their 
support given to the two defective political parties of APC and the PDP as both parties are with the same corrupt ideology, and has long been failing the citizens. I recommend that citizens should endeavour to try another political party to see the difference and in order to let our leaders and their political party godfathers know that citizens are not fools as they thought, and that citizens of Nigeria know there right and what is good for them. Through this Nigeria shall have a good leadership someday?

\section{REFERENCES :}

[1] The Hague Academy for Local Governance (2018). 7 conditions for successful citizens participation. Retrieved from https://thehagueacademy.com $>2018 / 05$ (Accessed 4th May, 2020).

[2] Eme, O. I. and Onuigbe R. A. (2015). Buhari Presidency and Ethnic Balancing in Nigeria. Faculty of Social Sciences Conference, University of Nigeria Nsukka, October 2015. Research gate, pp.1-26.

[3] Merriam, webster (1828). citizens www.merriam-webster.com (Accessed $19^{\text {th }} \mathrm{Feb}$ 2019).

[4] Collins Dictionary (2019). Definition of Citizen, https://collinsdictionary.com $>$ citizen $\left(29^{\text {th }}\right.$ November, 2019).

[5] Cambridge Dictionary (2019). Good governance, Cambridge university press, United State.
[6] International Fund for Agricultural Development (1999). Good governance; An overview, Executive Board-Sixty-seven session, Rome.

[7] OUTA (2019). Active Citizenry. www.outa.co.za. (Accessed $20^{\text {th }}$ Feb 2019). Part one (1) of the federal character principles.

[8] Jeremy, Bentham (1989). An introduction to the principles of Morales and legislation, https://en.m.wikipedia.org (Accessed 22 $2^{\text {nd }}$ February 2019)

[9] Toba, D. Alabi (2019) the killer herdsmen again struck in the Agatu community of Benue state, killing sixteen. Facebook page, International relations and political science scholars.

[10] Vanguard (2014). Full list of PDP Senators and Members that Defected to APC. www.vanguardngr.com (Accessed $22^{\text {nd }} F e b 2019$ ).

[11] Osewa, O. S. (2019). Terrorism in Nigeria: Causes, Consequences and Panacea. International Journal of Legal Studies (IJOLS), 6(2), 341-366.

[12] Anifowose, R. and Enemuo, F. (1999). Element of politics, Sam Iroanusi publications, Lagos, Nigeria. 